\title{
KEANEKARAGAMAN DAN KEPADATAN SPONS DI PERAIRAN LALOWARU SULAWESI TENGGARA
}

\section{The Diversity and Density of Sponge in The Lalowaru Waters, Southeast Sulawesi}

\author{
Hilda Yanti ${ }^{1}$, Ratna Diyah Palupi ${ }^{2}$, Rahmadani $^{3}$ \\ ${ }^{1}$ Mahasiswa Jurusan Ilmu Kelautan, \\ Fakultas Perikanan dan Ilmu Kelautan, Universitas Halu Oleo. \\ Jl. H.E.A Mokodompit Kampus Hijau Bumi Tridharma Anduonohu Kendari 93232, Telp/Fax: (0401) 3193782 \\ ${ }^{2}$ Surel: pratna97@yahoo.com \\ ${ }^{3}$ Surel: rahmamustafa47@gmail.com
}

\begin{abstract}
Abstrak
Spons sebagai salah satu hewan primitif yang hidup menetap dan bersifat filter feeder (menyaring). Hewan tersebut memberikan sumbangan yang penting terhadap komunitas bentik laut dan sangat umum dijumpai di perairan tropik dan sub tropik. Penelitian ini bertujuan untuk mengetahui keanekaragaman dan kepadatan spons di Perairan Lalowaru, Kabupaten Konawe Selatan. Pengambilan data ini dilaksanakan pada bulan April-Agustus 2016. Pengambilan data spons dilakukan dengan metode transek kuadrat. Garis transek sepanjang 50m dibentangkan tegak lurus pantai yang mewakili kondisi perairan pada kedalaman yang berbeda. Kemudian transek kuadrat ukuran $1 \mathrm{~m}^{2}$ diletakkan dengan jarak $5 \mathrm{~m}$ disetiap pengulangannya. Didapatkan bahwa keanekaragaman jenis spons di Perairan Lalowaru sebanyak 7 famili yaitu Agelasidae, Callyspongidae, Chalinidae, Irchinidae, Petrosiidae, Pseudoceratinidae, dan Microcionidae, 7 genus yakni Agelas , Callyspongia , Chalinula, Ircinia , Xestospongia, Pseudoceratina, dan Clatrhia . dan 243 individu. Kepadatan spons dilokasi penelitian dengan nilai kepadatan tertinggi terdapat pada genus spons Xestospongia dengan nilai 15,34 ind $/ 10 \mathrm{~m}^{2}$ dan terendah genus Pseudoceratina dengan nilai $0,34 \mathrm{ind} / 10 \mathrm{~m}^{2}$.
\end{abstract}

Kata kunci : Keanekaragaman, Kepadatan, Spons, Perairan Lalowaru

\begin{abstract}
Sponge is one of the primitive animals living sedentary and filter feeder. Sponge plays essential role to the marine benthic communities and is commonly found in tropical and sub-tropical waters. This research aims to determine the species diversity and density of the sponge in the Lalowaru Waters of South Konawe. Data were collected in April-Agust 2016 by using quadrat transect method. The $50 \mathrm{~m}$ longline transect was placed perpendicular to the beach representing the condition of the water at different depths. Transect with $1 \mathrm{~m}^{2}$ quadrat size was placed at a distance of $5 \mathrm{~m}$. The study found that the sponges diversity in Lalowaru waters was 243 individuals and included in families, namely Agelasidae, Callyspongidae, Chalinidae, Irchinidae, Petrosiidae, Pseudoceratinidae, and Microcionidae, and genera were found, namely Agelas s, Callyspongia , Chalinula , Ircinia , Xestospongia, Pseudoceratina, And Clatrhia . The highest sponge density at the study sites was in the genus Xestospongia with a velue of $15,34 \mathrm{ind} / \mathrm{m}^{2}$ and the lowest was in the genus Pseudoceratina with a velue of $0,34 \mathrm{ind} / \mathrm{m}^{2}$.
\end{abstract}

Keywords: Diversity, Density, Lalowaru Waters, Sponge

\section{Pendahuluan}

Spons merupakan organisme laut invertebrata yang berasal dari filum porifera.Spons sebagai salah satu hewan primitif yang hidup menetap dan bersifat filter feeder (menyaring). Hewan ini memberikan sumbangan yang penting terhadap komunitas bentik laut dan sangat umum dijumpai di perairan tropik dan sub tropik. Penyebaran mulai dari zona intertidal hingga zona subtidal suatu perairan.Spons memiliki manfaat yang tinggi diantaranya dalam bidang industri pertanian, kimia, maupun farmasi. Beberapa tahun terakhir ini para peneliti memperlihatkan perhatiannya pada spons, karena terdapat senyawa bahan alam didalamnya. Ekstrak metabolit dari spons mengandung senyawa bioaktif yang diketahui mempunyai sifat aktifitas seperti sitoksin, anti tumor, anti virus, anti inflamasi, anti fungi, anti leukimia, dan penghambat aktivitas enzim. Menurut (Pronzato dkk., 1999) berkaitan dengan senyawa bahan alam (metabolit sekunder) yang terkandung di dalam spons banyak dimanfaatkan dalam bidang farmasi, karena memiliki sifat bioaktif.

Keanekaragaman jenis spons pada suatu habitat umumnya ditentukan oleh kondisi perairan yang jernih dan tidak 
memiliki arus kuat, kondisi lingkungan mengharuskan spons tersebut selalu beradaptasi terhadap komponen-komponen fisik maupun biotik yang terdapat pada suatu perairan.

Perairan Lalowaru merupakan suatu perairan yang terletak di Kecamatan Moramo Utara dan memiliki suatu potensi sumberdaya hayati yang beragam untuk dikembangkan, akan tetapi habitat hidup organisme laut di perairan tersebut banyak mengalami degradasi sehingga kelestarian habitat organisme semakin berkurang. Sehingga sumber daya alam laut yang rusak tidak lain karena ulah manusia itu sendiri yang terus melakukan kegiatan penangkapan yang tidak ramah lingkungan seperti membom ikan dan terus melakukan eksploitasi dimana kegiatan tersebut dapat merusak habitat sumber daya alam laut tidak terkecuali organisme spons.

Beberapa wilayah Sulawesi Tenggara termasuk di perairan pulau-pulau kecil di Kabupaten Konawe Selatan masih minim informasi atau data mengenai biota laut, khususnya keanekaragaman spons salah satunya di Perairan Lalowaru. Berdasarkan penjelasan tersebut, maka penelitian ini perlu dilakukan untuk mengetahui keanekaraman dan kepadatan spons di Perairan Lalowaru karena spons merupakan salah satu organisme hayati laut yang memiliki potensi untuk dikembangkan.

\section{Bahan dan Metode}

Pengambilan data dilaksanakan pada bulan April-Agustus 2016 bertempat di Perairan Lalowaru, Kecamatan Moramo Utara, Provinsi Sulawesi Tenggara. Survey pendahuluan dilakukan untuk melihat lokasi awal penelitian secara menyeluruh. Hal ini bertujuan untuk mengetahui kondisi umum dan member gambaran keberadaan spons dalam menentukan lokasi penelitian, sehingga dapat member kemudahan pada saat melakukan penelitian.

Penandaan stasiun penelitian menggunakan GPS untuk menandai titik stasiun penelitian yang akan diteliti. Penentuan titik stasiun menggunakan metode Purposive Samplingdengan melihat kondisi lingkungan seperti substrat dan kedalaman serta dapat mewakili keberadaan organisme spons.

Penentuan stasiun dilakukan berdasarkan survey pendahuluan dengan melihat keberadaan organisme spons sebagai berikut: Stasiun1, terletak pada koordinat (4¹'10.4"LS -122 $\left.39^{\prime} 47.1 " B T\right)$. Berada pada daerah yang memiliki substrat lumpur dan ditemukan tumbuhan spot-spot lamun. Stasiun 2 , terletak pada koordinat $\left(4^{\circ} 1^{\prime} 5.43^{\prime \prime} \mathrm{LS}-\right.$ $\left.122^{\circ} 39 ' 59,40 " B T\right)$ daerah ini memiliki substrat pasir berlumpur dan ditemukannya tumbuhan spot-spot lamun. Stasiun 3, terletak pada koordinat $\left(4^{\circ} 1{ }^{\prime} 3.14 " \mathrm{LS}-\right.$ $\left.122^{\circ} 40^{\prime} 3.78^{\prime \prime} \mathrm{BT}\right)$ daerah yang memiliki substrat pecahan karang.

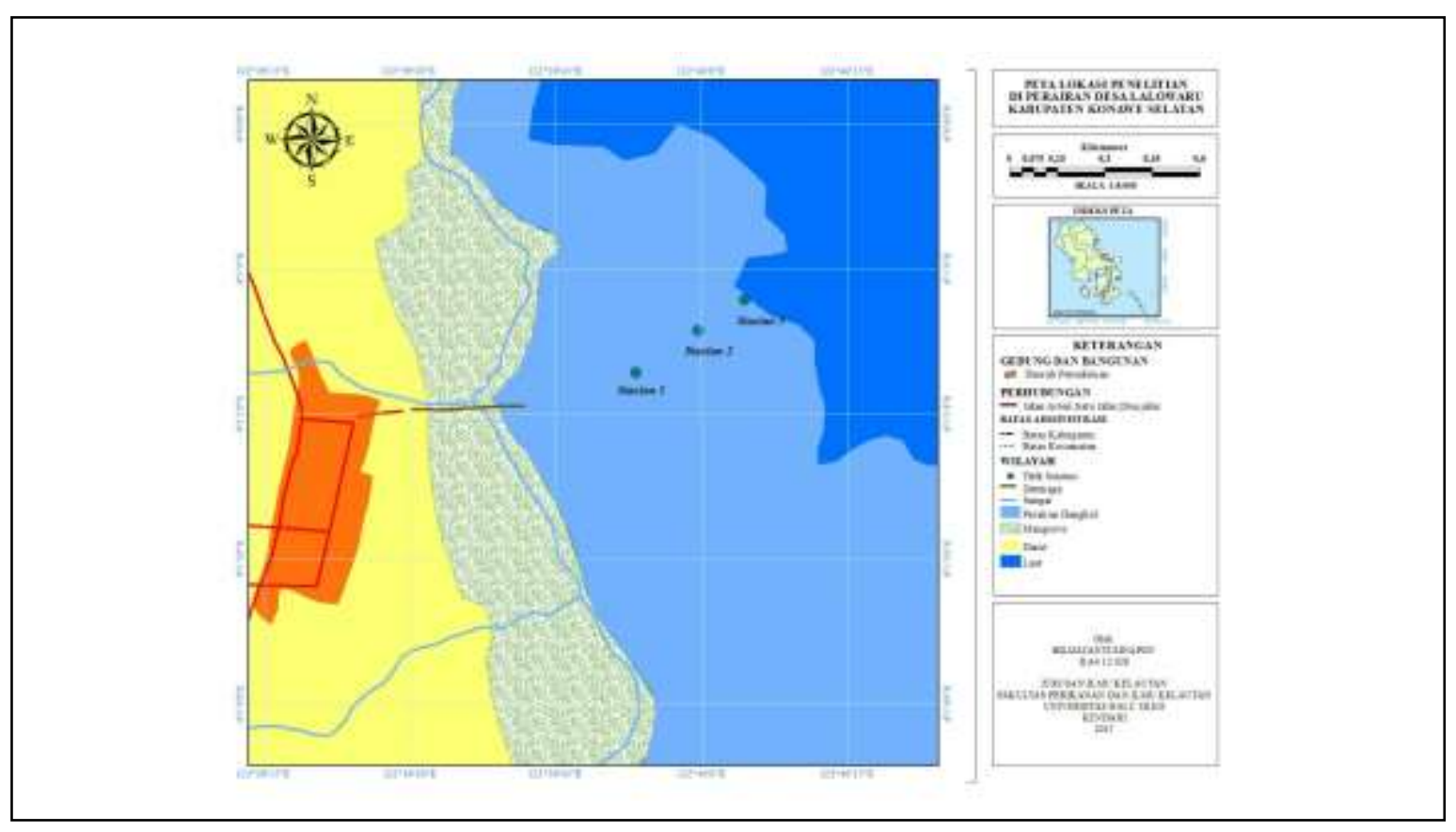

Gambar1. Peta Lokasi Penelitian di Perairan Lalowaru Kecamatan Moramo Utara 


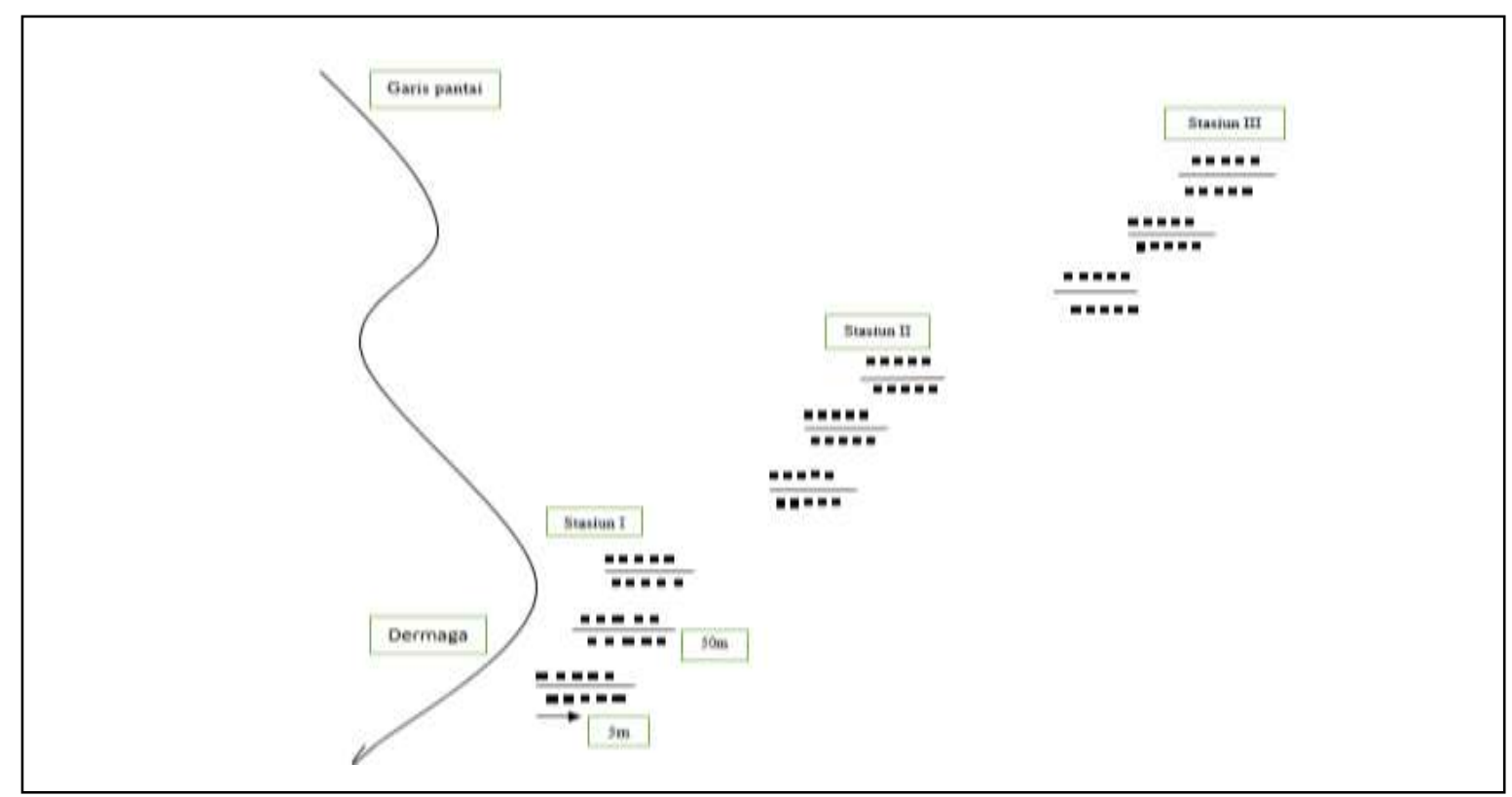

Gambar 2. Skema Pengambilan Plot Transek

Pengambilan data penelitian keanekaragaman jenis dan kepadatan spons menggunakan transek kuadrat dengan luasan $1 \mathrm{~m}^{2}$. Garis transek sepanjang $50 \mathrm{~m}$ dibentangkan tegak lurus garis pantai yang mewakili kondisi perairan pada kedalaman yang berbeda dan juga tipe substrat. Kemudian transek kuadrat ukuran $1 \mathrm{~m}^{2}$ diletakkan dengan interval $5 \mathrm{~m}$ sepanjang line transect sehingga diperoleh 3 kali pengulangan ditiap stasiun (Gambar 2). Sampel spons yang telah dihitung laludiambil salah satunya untuk mewakili tiap jenisnya dan didokumentasikan serta diidentifikasi tiap jenis.Hal ini sesuai dengan pernyataan Pratama (2014), dimana pengambilan data spons dilakukan dengan metode kuadrat yaitu: dengan menggunakan ukuran $1 \times 1 \mathrm{~m} 2$ yang diletakan secara acak dan pada setiap titik sampling dilakukan tiga ulangan.

Pengukuran parameter kualitas lingkungan habitat sponsberupa kecepatan arus, kedalaman, suhu perairan, salinitas, dan derajat keasaman $(\mathrm{pH})$ dilakukan disetiap stasiun pengamatan dan pengukuran dilakukan sebanyak 3 kali ulangan dalam setiap kali pengambilan data.

Data kepadatan spons diperoleh dengan menggunakan rumus Brower $d k k$ (1998), yaitu: $K=\frac{n}{A}$

Keterangan :

$\mathrm{K}$ = kepadatan individu spons

$\mathrm{N}=$ jumlah genus spons $\left(\mathrm{ind} / \mathrm{m}^{2}\right)$

$\mathrm{A}=$ Luasan area transek $\left(\mathrm{m}^{2}\right)$
Penelitian perhitungan spons ini dihitung dengan menggunakan luasan $10 \mathrm{~m}^{2}$

Keanekaragaman jenis spons dianalisa secara deskriptif dan melihat potensi (biodiversity) yang terdapat pada organisme spons.

\section{Hasil dan Pembahasan}

Berdasarkan hasil penelitian jumlah jenis spons yang ditemukan di perairan Lalowaru berjumlah 7 famili dan 7 jenis. Keanekaragaman jenis tertinggi ditemukan pada stasiun I (6 jenis) dan terendah pada stasiun III (3 jenis). Hal ini disebabkan oleh kondisi fisik perairan pada stasiun III yang kurang mendukung kehidupan spons. Stasiun III memiliki kecepatan arus yang rendah $(0,04$ $\mathrm{m} / \mathrm{det}$ ) dibandingkan dengan stasiun I dan II. Arus berperan penting dalam proses sirkulasi air dalam perairan terhadap jumlah nutrien yang mampu bergerak bebas untuk suplay makanan spons. Kecepatan arus sangat dibutuhkan spons antara lain sebagai penyuplai oksigen dan makanan (berupa plankton) serta bermanfaat untuk membersihkan sedimen yang menempel pada tubuhnya. Hal ini sesuai dengan hasil penelitian Pratama (2014), bahwa stasiun yang memiliki kecepatan arus yang tinggi ditemukan jumlah jenis spons yang banyak dibandingkan pada stasiun yang kecepatan arus rendah. Kecepatan arus berperan penting dalam proses sirkulasi air dalam perairan terhadap jumlah nutrien yang dibawah tepi perairan. 
Tabel 1. Keanekaragaman Spons di Perairan Lalowaru

\begin{tabular}{|c|c|c|c|c|}
\hline Stasiun & Filum & Kelas & Famili & Genus/JenisSpons \\
\hline I & Porifera & Demospongiae & $\begin{array}{l}\text { Agelasidae } \\
\text { Callyspongidae } \\
\text { Chalinidae } \\
\text { Irchinidae } \\
\text { Petrosiidae } \\
\text { Pseudoceratinidae }\end{array}$ & $\begin{array}{l}\text { Agelas sp. } \\
\text { Callyspongia sp. } \\
\text { Chalinula sp. } \\
\text { Ircinia sp. } \\
\text { Xestospongia sp. } \\
\text { Pseudoceratinasp. }\end{array}$ \\
\hline II & Porifera & Demospongiae & $\begin{array}{l}\text { Agelasidae } \\
\text { Irchinidae } \\
\text { Petrosiidae } \\
\text { Pseudoceratinidae }\end{array}$ & $\begin{array}{l}\text { Agelas } \mathrm{sp} . \\
\text { Ircinia } \mathrm{sp} . \\
\text { Xestospongia } \mathrm{sp} . \\
\text { Pseudoceratina } \mathrm{sp} .\end{array}$ \\
\hline III & Porifera & Demospongiae & $\begin{array}{l}\text { Callyspongidae } \\
\text { Microcionidae } \\
\text { Petrosiidae }\end{array}$ & $\begin{array}{l}\text { Callyspongia sp. } \\
\text { Clatrhia sp. } \\
\text { Xestospongia sp. }\end{array}$ \\
\hline
\end{tabular}

Tabel 2. Kepadatan Spons di Perairan Lalowaru

\begin{tabular}{clc}
\hline Stasiun & Genus/Jenis Spons & $\left(\right.$ Individu/10m $\left.^{\mathbf{2}}\right)$ \\
\hline \multirow{2}{*}{ I } & Agelas sp. & 1,00 \\
& Callyspongia sp. & 2,00 \\
& Chalinula sp. & 1,00 \\
& Ircinia sp. & 3,34 \\
& Xestospongia sp. & 15,00 \\
& Pseudoceratinasp. & 3,00 \\
\hline \multirow{2}{*}{ II } & Agelas sp. & 3,34 \\
& Ircinia sp. & 0,67 \\
& Xestospongia sp. & 15,34 \\
& Pseudoceratina sp. & 0,34 \\
\hline \multirow{3}{*}{ III } & Callyspongia sp. & 5,34 \\
& Clatrhia sp. & 1,34 \\
& Xestospongia sp. & 0,34 \\
\hline
\end{tabular}

Tabel 3. Parameter Fisika dan Kimia Perairandi PerairanLalowaru

\begin{tabular}{lccc}
\multicolumn{1}{c}{$\begin{array}{c}\text { Parameter Fisika dan Kimia } \\
\text { Perairan }\end{array}$} & Stasiun I & Stasiun II & Stasiun III \\
\hline Suhu $\left({ }^{0} \mathrm{C}\right)$ & 30 & 31 & 32 \\
Salinitas (ppt) & 37 & 35 & 35 \\
$\mathrm{pH}$ & 7 & 7 & 7 \\
KecepatanArus (m/det) & 0,052 & 0,039 & 0,04 \\
Kedalaman (m) & 1,15 & 1,5 & 2 \\
Kecerahan (\%) & 92 & 95 & 97 \\
\hline
\end{tabular}




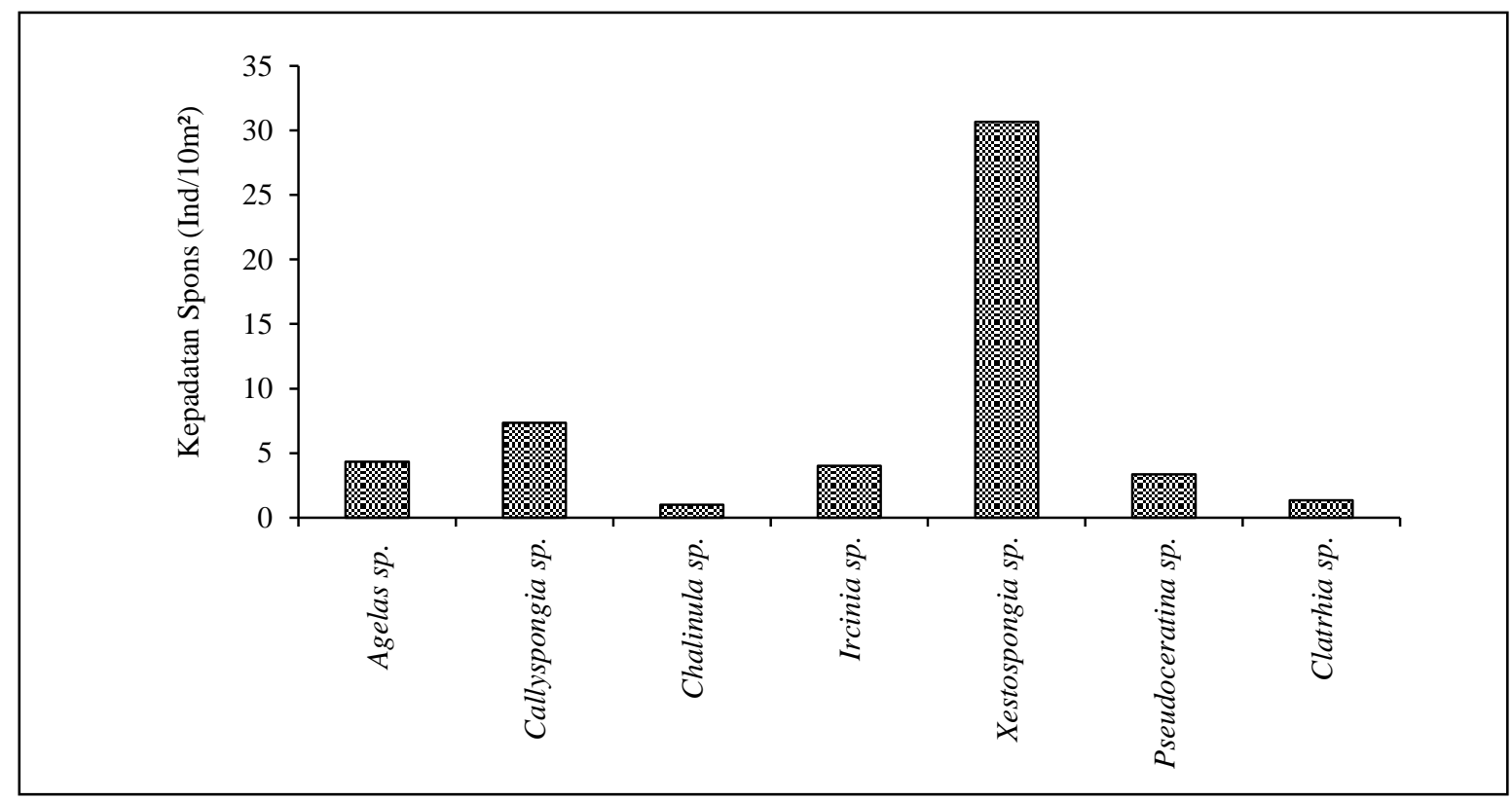

Gambar 3. Grafik Kepadatan Total Jenis Spons

Hasil Pengukuran kecepatan arus pada setiap stasiun selama penelitian berkisar antara 0,039-0,052 m/det. Kecepatan arus tertinggi pada stasiun I yaitu $0,052 \mathrm{~m} / \mathrm{det}$, dan yang terendah terdapat pada stasiun II yaitu $0,039 \mathrm{~m} /$ det. Perbedaan nilai kecepatan arus pada ketiga stasiun pengamatan tersebut menunjukkan bahwa masih dalam batas toleransi optimum organisme spons,pada stasiun I dan II jenis spons Xestospongia sp. ditemukan memiliki nilai lebih tinggi hal ini disebabkan karena jenis ini menyukai perairan yang memiliki suhu yang normal. Berdasarkan (Tabel 4) Stasiun I dan II memiliki kisaran suhu 30-32. Menurut Storr (1976), Spons tumbuh pada kisaran suhu dan arus optimal dan didaerah empat musim suhu merupakan faktor lingkungan utama yang mengatur reproduksi spons berkaitan dengan perubahan suhu yang mencolok pada setiap musimnya. Famili Petrosiidae merupakan famili yang umum ditemukan di perairan dangkal dan dalam dengan temperatur yang relatif hangat. Begitu pula pada famili Petrosiidae, spesies Xestospongia testudinaria merupakan spons yang memiliki sebaran luas tetapi memiliki kecenderungan berada di rataan terumbu di daerah intertidal (Iwenda ,2013).

Beberapa jenis spons juga ditemukan pada stasiun I dan II diantaranya Callyspongia sp, Xestospongia sp, dan Agelas sp jenis-jenis spons tersebut mempunyai kemampuan toleransi kondisi oseanografi ekstrim seperti kekeruhan tinggi dan kecepatan arus yang rendah. Parameter oseanografi yang mempengaruhi adalah kekeruhan rendah, salinitas tinggi dan kecepatan arus tinggi. Reseck (1988) mengatakan bahwa ada lima faktor ekologis yang sangat memmengaruhi bentuk dan pertumbuhan spons laut, antara lain kedalaman air, struktur dasar, arus air, suhu air, dan salinitas

Pertumbuhan spons di perairan Lalowaru umumnya pendek dan merayap hal ini dikarenakan adanya lingkungan yang kurang stabil, Menurut Storr (1976), beberapa jenis spons dapat bertahan hidup pada kedalaman sampai $20 \mathrm{~m}$ asalkan kebutuhan sinar matahari mencukupi serta keadaan lingkungannya yang stabil. Keanekaragaman Jenis spons ini didukung oleh kondisi lingkungan spons itu sendiri. Perbedaan tingkat keanekaragaman jenis di setiap stasiun ini sangat dipengaruhi oleh faktor fisik perairan seperti kecepatan arus dan juga kecerahan oleh karna itu lingkungan selalu menjadi faktor penting untuk mendukung habitat organisme diperairan.

Kondisi perairan memiliki peranan penting dalam mendukung kehidupan spons. Kondisi perairan yang sesuai dengan kehidupan spons yang di alam menyebabkan tingkat kepadatan spons semakin tinggi. Kondisi oseanografi meliputi arus, suhu air, salinitas, $\mathrm{pH}$, kekeruhan, dan kecerahan yang diukur sebagai faktor yang mempengaruhi kepadatan famili spons. 
Kepadatan spons yang ditemukan pada semua stasiun penelitian memiliki nilai kepadatan yang berbeda. Hal ini diakibatkan spons yang hidup soliter dan juga dipengaruhi oleh faktor fisik kimia perairan. Spons sangat rentan dengan perubahan kondisi perairan dimana kepadatan spons ini didukung oleh kondisi lingkungan spons itu sendiri. Perbedaan tingkat kepadatan di setiap stasiun sangat dipengaruhi oleh faktor fisik perairan oleh karena itu lingkungan selalu menjadi faktor pentingsebagai bahan rujukan yang harus diamati. Selain bahan organik terlarut kecerahan juga menjadi salah satu parameter indikator keberadaan spons(Wood, 1983).

Kepadatan spons yang paling tinggi terdapat pada stasiun II jenis Xestospongia sp.dengan kepadatan $15,34 \mathrm{ind} / 10 \mathrm{~m}^{2}$. Spons jenis ini juga banyak ditemukan. Hal ini disebabkan karena jenis Xestospongia sp. Mampu beradaptasi disemua tipe substrat perairan. Spons Xestospongia sp. merupakan salah satu jenis spons yang banyak terdapat di perairan Indonesia (Krisyunida, 2011). Stasiun III juga dengan tingkat kecerahan yang tinggi yaitu $97 \%$ sehingga mempengaruhi kehidupan spons.Barnes (1999) dalam Haris (2013), bahwa spons sangat menyukai perairan yang cukup jernih karena spons termasuk plankton feeder. Spons mampu menyaring air dan menyerap zat organik yang larut dalam air laut. Kepadatan spons akan terhambat akibat dari adanya kecerahan perairan yang rendah (sedimentasi tinggi) sehingga besar kemungkinan menghambat perkembangan spons (Samawi $d k k$. 2009).

FamiliCallyspongidae, Petrosiidae, Chondrillidae, dan Theonellidae merupakan organisme spons kedua yang paling sering ditemukan. Hal ini disebabkan karena kondisi oseanografi yang cukup alami untuk kehidupan spons. Menurut Rani \& Samawi (2003), bahwa famili Callyspongidae, Petrosiidae, Chondrillida dan Theonellida sering ditemukan pada kondisi Oseanografi yang relatif masih alami.

Selain itu famili yang ditemukan seperti dari famili Agelasidae, Chalinidae, Irchinidae, dan Microcionidae hanya saja dengan kepadatani jenis yang tidak begitu melimpah.Spons dengan jumlah yang besar umumnya dipengaruhi oleh ruang untuk tumbuh. Namun pada beberapa famili yang tidak dominan umumnya tumbuh di sela-sela karang dan bentuknya kecil, pendek dan becabang-cabang sehingga dapat bersaing dengan organisme lain. Menurut Amir dan Budiyanto (1996), bahwa spons dapat berkompetisi dengan alga dan karang dalam mendapatkan cahaya dimana spons dapat tumbuh di antar sela-sela karang dan bentuk bercabang.

\section{Kesimpulan}

Berdasarkan hasil pembahasan keanekaragaman jenis dan kepadatan sponsdiperairan Lalowaru dapat disimpulkan sebagai berikut:

1. Keanekaragaman spons yang ditemukan yaitu sebanyak 5 ordo, 7 famili, 7 Genus, dan 243 individu.

2. Kepadatan spons dilokasi penelitian dengan nilai kepadatan tertinggi terdapat pada Genus spons Xestospongia 15,34 Ind $/ 10 \mathrm{~m}^{2}$ dan terendah Genus Pseudoceratina dengan nilai 0,34 Ind $/ 10 \mathrm{~m}^{2}$

\section{Daftar Pustaka}

Abrar, M dan A.E.W. Manupputy. 2008. Inventarisasi dan Sebaran Biota Ascidian di Terumbu Karang Perairan Berau, Kalimantan Timur. P2OLembaga Ilmu Pengetahuan Indonesia. Jakarta.

Amir, I., dan Budiyanto, A., 1996., Mengenal Spons Laut (Demospongiae) Secara Umum. LIPI.Oseana. 21(2):15-30. Jakarta.

Brower, J.E., J.H. Zar, and C.N. von Ende. 1989. Field And Laboratory Methods For General Ecology. Third Edition. WM.C. Brower Publisher, Dobuque, USA.

David and Oskar, 1993. RZ, Marine Biotechnology, vol 1, Plenum Press, New York, 1993, 12-13.

Dohrmann, M., Janussen, D., Reitner, J., Collins, A. G., and Worheide, G. (2008). Phylogeny and Evolution of glass sponge (Porifera, Hexactinnelida). Systematic Biology 57, 388-405.

Haris A, 2013. Sponge : Biologi dan Ekologi. Fakultas Ilmu Kelautan dan Perikanan - Universitas Hasanuddin, Makassar.

Haris, A., Werorilangi, S., dan Gosalam, G. 2013.KomposisiJenisdan Kepadatan Spons (Porifera: Demospongiae) Di Kepulauan Spermonde Kota Makassar. 
Tesis. Fakultas Ilmu Kelautan dan Perikanan, Universitas Hasanuddin. Makassar.

Pratama, 2014. Distribusi dan Kelimpahan di Perairan Pulau Karammasang Kabupaten Polewali Mandar: Keterkaitan dengan Terumbu Karang dan Oseanografi Perairan. SkripsiFakultas Ilmu Kelautan dan Perikanan, Universitas Hasanuddin. Makassar.

Rachmat , R. 2007. Spons Indonesia Bagian Timur Keragaman , Distribusi, Kelimpahan, dan Kandungan Metabolit Sekundernya. J. Oseanologi dan Limnologi di Indonesia. 33 : 123-138.

Romimohtarto, K. dan Juwana S. 1999. Biologi Laut. Ilmu Pengetahuan tentang Biota Laut. Pusat Penelitian dan Pengembangan Oseanologi- LIPI.

Romimohtarto, K. dan S. Juwana. 2001. Biologi laut : Ilmu pengetahuan tentang biota laut. Jakarta : Pusat Penelitian dan Pengembangan Oseanologi-LIPI. Jakarta. Romimohtarto dan Juwana, 2001).

Samawi M.F, Rani C dan Ramli 2009. Keterkaitan antara Kondisi Oseanografi dengan Komposisi Jenis dan Kepadatan Sponge Laut di Kepulauan Spermonde. Faculty of Marine Science and Fishery, Hasanuddin University. Makassar.

Satari, RR, Penelitian Produk Alam laut di Indonesia, arah dan prospek, Seminar Nasional Kimia Bahan Alam, Jakarta 1999, 29-37.

Suparno, 2005. Kajian bioaktif spons laut (forifera: demospongiae) suatu peluang alternatif pemanfaatan ekosistem karang indonesia dalam dibidang farmasi. Makalah Pribadi Falsafah Sains (PPs 7002) : Sekolah Pasca Sarjana Institut Pertanian Bogor

Storr. 1976b . Field observation of sponge reactions as related to their ecology. In: Harrison, F.W. and R.R. Cowden (eds.) Aspec of Biology. New York: Academic Press.

Tanaka, J., S. Aoki, T. HIGA, M. Kobayashi, R. Rachmaniar \& N.J. DE Voogd 2002. Indonesian Marine Sponges. Osaka University, Osaka: 221pp. 